\title{
Foraging strategies of the ant Ectatomma vizottoi (Hymenoptera, Formicidae)
}

\author{
Luan D. Lima ${ }^{1} \&$ William F. Antonialli-Junior ${ }^{1}$
}

\begin{abstract}
${ }^{1}$ Laboratório de Ecologia, Centro Integrado de Análise e Monitoramento Ambiental, Universidade Estadual de Mato Grosso do Sul, Dourados. Rodovia Dourados-Itahum, km 12,5, Caixa-Postal 351,79804-970 Dourados-MS, Brasil. luandiaslima@hotmail.com; williamantonialli@yahoo.com.br
\end{abstract}

\begin{abstract}
Foraging strategies of the ant Ectatomma vizottoi (Hymenoptera, Formicidae). Foraging activity may be limited by temperature, humidity, radiation, wind, and other abiotic factors, all of which can affect energy costs during foraging. Ectatomma vizottoi's biology has only recently been studied, and no detailed information is available on its foraging patterns or diet in the field. For this reason, and because foraging activity is an important part of the ecological success of social insects, the present study aimed to investigate E. vizottoi's foraging strategies and dietary habits. First, we determined how abiotic factors constrained E. vizottoi's foraging patterns in the field by monitoring the foraging activity of 16 colonies on eight different days across two seasons. Second, we characterized $E$. vizottoi's diet by monitoring another set of 26 colonies during peak foraging activity. Our results show that $E$. vizottoi has foraging strategies that are similar to those of congeneric species. In spite of having a low efficiency index, colonies adopted strategies that allowed them to successfully obtain food resources while avoiding adverse conditions. These strategies included preying on other ant species, a foraging tactic that could arise if a wide variety of food items are not available in the environment or if E. vizottoi simply prefers, regardless of resource availability, to prey on other invertebrates and especially on other ant species.
\end{abstract}

KEYWORDS. Activity period; behavior; Ectatomminae; Insecta; nourishment.

Ants are poikilotherms, and their foraging activity is therefore limited by temperature, humidity, radiation, wind and other abiotic factors that might affect the time or energy costs of foraging (Traniello et al. 1984; Traniello 1989; Pol \& Casenave 2004). Temperature is one of the primary factors affecting the foraging dynamics of many ant species. Higher temperatures increase ant metabolic rates, resulting in higher energy costs (Nielsen 1986). Traniello et al. (1984) observed that workers of Formica schaufussi Mayr, 1866 rejected smaller, less-profitable prey at low temperatures but accepted them at high temperatures. According to Heinrich (1993), humidity, the availability of food resources, and temperature, in particular, mediate the seasonal activity and daily movement of many insect groups.

Ants have very broad temperature ranges over which they are active (Heinrich 1993), though some species can forage more intensely at specific times of the day. McCluskey (1987) and Valenzuela-González et al. (1995) reported that the number of foragers of Ectatomma tuberculatum (Olivier, 1792) leaving the nest markedly increased at dusk. The number remained high during the first half of the night but dropped at dawn and remained low throughout the day. Ectatomma ruidum (Roger, 1860), on the other hand, showed the opposite pattern, with forager numbers high during the day and low at night (Lachaud et al. 1984; McCluskey 1987; Lachaud 1990).

Members of the genus Ectatomma Smith, 1858 are generalist predators that feed on a variety of small arthropods and annelids and may also collect extrafloral nectar and hemipteran honeydew (Fernández 1991; Oliveira \& Brandão 1991; Del-Claro \& Oliveira 1999; Pie 2004). In previous studies, it has been shown that E. ruidum, E. tuberculatum, E. brunneum Smith, 1858 and E. opaciventre (Roger, 1861) are generalists and can be dominant arboricolous or terricolous species in cocoa, coffee and maize plantations. They are both opportunistic predators and carrion-feeders, and most of the items they collect are arthropods (Pratt 1989; Lachaud 1990; Perfecto 1990; Giannotti \& Machado 1992; Majer et al. 1994; Valenzuela-González et al. 1995; Lachaud et al. 1996; IbarraNúñez et al. 2001; Pie 2004; Tofolo et al. 2011).

The biology of Ectatomma vizottoi Almeida, 1987 has only recently been studied (Vieira et al. 2007, 2009, 2010, 2012), and a detailed investigation of the species' foraging patterns or diet in the field has yet to be conducted. For this reason, and because foraging activity is an important part of ecological success in social insects, the present study aimed to investigate the foraging strategies and dietary habits of $E$. vizottoi.

\section{MATERIAL AND METHODS}

The study was conducted from July 2009 to July 2010 in an area with $84 \mathrm{~m}^{2}$ on the campus of the Mato Grosso do Sul State University (UEMS) in Dourados, Brazil (22 $13^{\prime} 16^{\prime \prime} \mathrm{S}$; $\left.54^{\circ} 48^{\prime} 20^{\prime \prime} \mathrm{W}\right)$. At the site where the study took place, grass and shrub species are dominant. Mato Grosso do Sul has a humid, subtropical climate. The rainy season typically lasts from November through April, and the dry season lasts from May through October (Zavatini 1992).

In the first part of our study, we monitored the influence of three abiotic factors, temperature, humidity, and light intensity, on the fullest possible range of E. vizzotoi's foraging 
activity throughout the year. Sixteen colonies were observed from 06:00 to $18: 30 \mathrm{~h}$ on eight different days; observations were repeated four times during the dry season and four times during the rainy season. To avoid disturbing the colony foraging behavior during early nightfall, we used a lantern covered with red cellophane (Del-Claro 2004).

Two colonies were observed per day; each pair of colonies was located within a radius of two meters so that the observer could monitor one colony during the first $15 \mathrm{~min}$ utes of each hour and the second colony during the next 15 minutes. At every 15 minutes, the temperature $\left({ }^{\circ} \mathrm{C}\right)$, relative humidity (\%), and light intensity (Lux) were recorded during observations using a thermo-hygrometer and a photometer. During the observation period, the numbers of workers that left and entered the nest were recorded. Each of the 16 colonies was observed only once.

The forager efficiency index was calculated for the two seasons as follows: efficiency index $=$ (number of incoming foragers carrying food x 100)/total number of incoming foragers (Giannotti \& Machado 1992; Chagas \& Vasconcelos 2002). To avoid influencing the intensity of colony foraging activity, we recorded the number of times foragers brought a given food item back to the nest, but we did not collect the food item.

The results were analyzed using Spearman's correlation analysis in the PAST program (Hammer et al. 2001). A regression tree was also used to determine which abiotic factors most influenced E. vizzotoi's foraging activity; the number of ants foraging was the response variable and temperature, relative humidity, and light intensity were the explanatory variables. A regression tree was used to examine the influence of abiotic factors on harvesting success; the number of incoming foragers carrying food items was the response variable and temperature, relative humidity, and light intensity were the explanatory variables. The regression trees were generated using SYSTAT 10 software (Wilkinson 2000). They are constructed by repeatedly splitting the data according to a simple rule chosen based on a single explanatory variable. At each split, the data are partitioned into two mutually exclusive groups, each of which is as homogeneous as possible with respect to the response variable (De'ath \& Fabricius 2000; Prasad et al. 2006). The output is a tree diagram with branches that are determined by the splitting rules and a series of terminal nodes that contain the mean response (Prasad et al. 2006).

In the second part of our study, we used the results obtained in the first part of the study to identify periods of peak foraging activity during the dry season and the rainy season. During these foraging peaks, we monitored a second group of 26 colonies for a total of 252 hours to characterize $E$. vizottoi's diet; only one colony was monitored per day. During the first 15 minutes of each hour over a period of four hours, we collected the items that foragers brought to the nest. Prey items or other materials were removed from the mandibles of returning foragers with tweezers and preserved in $70 \%$ ethanol until further identification could take place.

\section{RESULTS}

The results of the Spearman's correlation analysis showed that temperature $(\mathrm{P}=0.0029 ; \mathrm{R}=-0.7527)$, relative humidity $(\mathrm{P}=0.0092 ; \mathrm{R}=0.6888)$, and light intensity $(\mathrm{P}=0.0305$; $\mathrm{R}=-0.5989$ ) were correlated with $E$. vizottoi's foraging activity. However, the regression trees suggested that temperature was the most limiting factor (Fig. 1).

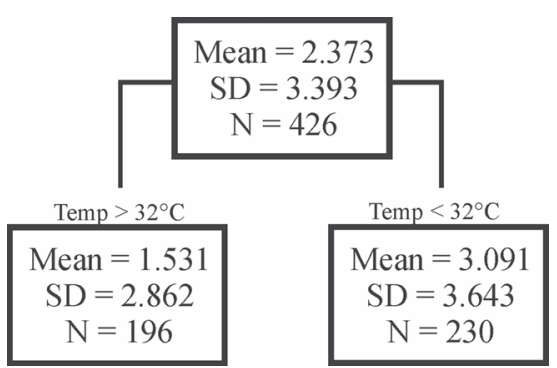

Fig. 1. Regression tree of the relationship between the number of foragers of Ectatomma vizottoi leaving the nest and temperature throughout the day.

When temperatures were below $32^{\circ} \mathrm{C}$ (Fig. 1), the number of workers involved in foraging activity was higher; however, no foraging activity was observed below $14{ }^{\circ} \mathrm{C}$. Furthermore, the mean number of incoming ants carrying food items was higher at temperatures below $32^{\circ} \mathrm{C}$ (Fig. 2).

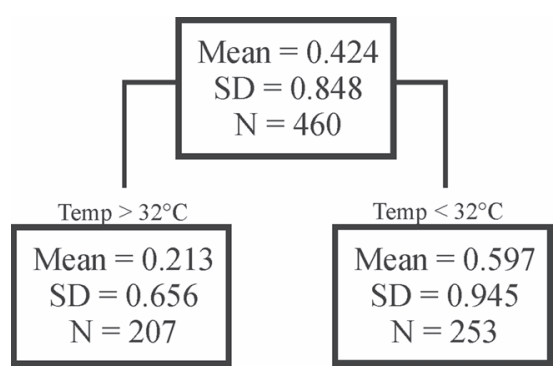

Fig. 2. Regression tree of the relationship between the number of incoming foragers of Ectatomma vizottoi carrying prey and temperature throughout the day.

Foraging activity peaked in the early morning from 07:00 to $09: 30 \mathrm{~h}$ and in the late afternoon between 15:00 and 18:30 $\mathrm{h}$ and increased starting at nightfall, regardless of the season (Fig. 3). Ecatomma vizottoi's efficiency index was $7.02 \%$ for the dry season and $11.36 \%$ for the rainy season.

Foragers collected mostly other species of ants, regardless of the season. Taken together, other species of ants composed $64.5 \%(n=89)$ of the total sample (Tables I and II), which included species of Camponotus Mayr, 1861 ( $\mathrm{n}=63$; $45.65 \%$ of the sample), Pheidole Westwood, 1839 ( $\mathrm{n}=17$; $12.32 \%$ of the sample), Azteca Forel, $1878(\mathrm{n}=4 ; 2.88 \%)$, Brachymyrmex Mayr, $1868(\mathrm{n}=2 ; 1.44 \%)$, other species of Ectatomma $(\mathrm{n}=2 ; 1.44 \%)$, and Hypoponera Santschi, 1938 $(\mathrm{n}=1 ; 0.72 \%)$. 

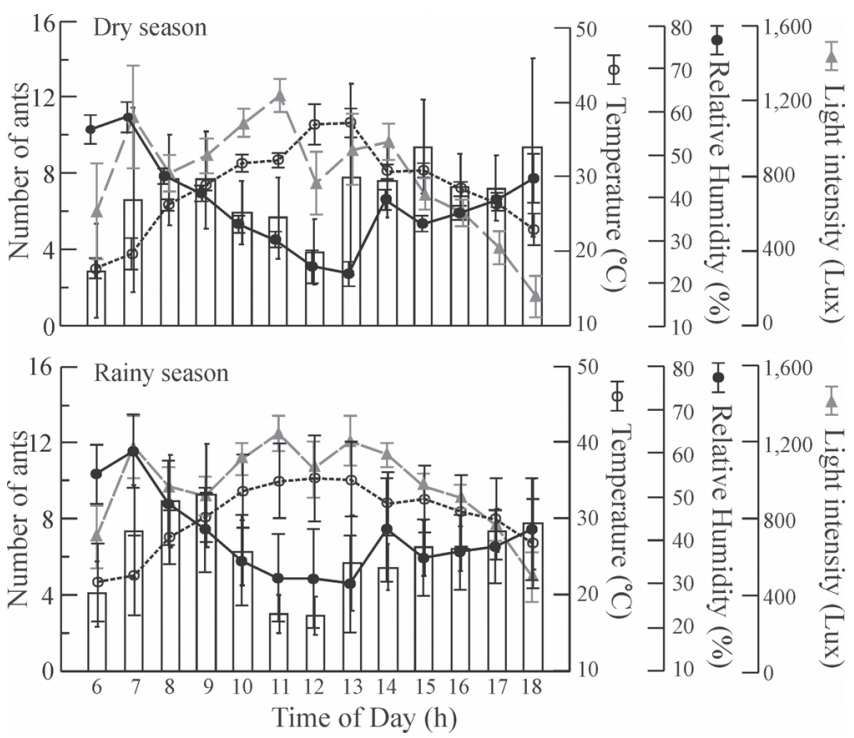

Fig. 3. Daily and seasonal variation in the foraging activity of 16 colonies of Ectatomma vizottoi in Dourados, Brazil. Colony activity was observed during the dry season (May-Oct) and the rainy season (Nov-Apr) from 06:00 to $18: 30 \mathrm{~h}$. Temperature $\left({ }^{\circ} \mathrm{C}\right)$, relative humidity $(\%)$, and light intensity (Lux) were measured concurrently with foraging activity.

They also collected adults of other arthropod orders, including Isoptera, Arachnida, Diptera, Coleoptera, Orthoptera, Hemiptera, and other Hymenoptera as well as Lepidoptera larvae, and plant and animal material that could not be identified (Table I). Individual prey items were always intact, even when they were larger than the foragers. We always observed workers of E. vizottoi foraging alone, and we never observed any evidence of recruitment.

\section{DISCUSSION}

The three abiotic factors we measured were correlated with foraging activity. However, since the regression trees suggested that foraging activity was primarily limited by temperature, relative humidity and light intensity likely indirectly influenced foraging activity because they covaried with temperature (Figs. 1, 2, and 3). Furthermore, abiotic factors such as temperature and humidity may interact with biotic factors such as resource availability and competition to generate different ant foraging activity patterns since both sets of factors may affect metabolic costs and therefore possibly influence prey selection (Traniello et al. 1984; Traniello 1989; Hahn \& Wheeler 2002).

The Spearman's correlation analysis showed that foraging activity was negatively correlated with temperature and light intensity and positively correlated with relative humidity. The regression tree suggested that temperature had a crucial influence: $E$. vizottoi generally foraged at temperatures of $32^{\circ} \mathrm{C}$ or below. Once the temperature exceeded $32^{\circ} \mathrm{C}$, foraging activity decreased (Fig. 1). However, there was also a minimal thermal limit since $E$. vizottoi did not forage at temperatures below $14^{\circ} \mathrm{C}$. This result suggests that $E$. vizottoi foragers must avoid dehydration or other kinds of non-optimal
Table I. Food items collected by foragers of Ectatomma vizottoi in Dourados, Brazil in the dry season and rainy season in 2009 and 2010.

\begin{tabular}{lccc}
\hline \multicolumn{1}{c}{ Food item } & Dry season (May-Oct) & Rainy season (Nov-Apr) & Total \\
\hline Arachnida & 0 & 1 & 1 \\
Coleoptera & 1 & 3 & 4 \\
Diptera & 5 & 3 & 8 \\
Hemiptera & 1 & 7 & 8 \\
Isoptera & 4 & 3 & 7 \\
Lepidoptera & 4 & 3 & 7 \\
Orthoptera & 0 & 2 & 2 \\
Other Formicidae & 40 & 49 & 89 \\
Other Hymenoptera & 2 & 1 & 3 \\
Unidentified items & 1 & 8 & 9 \\
\hline Total & 58 & 80 & 138 \\
\hline
\end{tabular}

Table II. Ants collected by foragers of E. vizottoi in Dourados, Brazil during the dry season and rainy season in 2009 and 2010.

\begin{tabular}{|c|c|c|c|}
\hline Ant species & Dry season (May-Oct) & Rainy season (Nov-Apr) & Total \\
\hline Azteca sp.1 & 4 & 0 & 4 \\
\hline Brachymyrmex sp. 1 & 0 & 2 & 2 \\
\hline Camponotus sp. 1 & 8 & 7 & 15 \\
\hline Camponotus sp. 2 & 3 & 2 & 5 \\
\hline Camponotus sp. 3 & 3 & 1 & 4 \\
\hline Camponotus sp. 4 & 5 & 6 & 11 \\
\hline Camponotus sp. 5 & 1 & 1 & 2 \\
\hline Camponotus sp. 6 & 1 & 6 & 7 \\
\hline Camponotus sp. 7 & 1 & 0 & 1 \\
\hline Camponotus sp. 8 & 1 & 0 & 1 \\
\hline Camponotus sp. 9 & 2 & 0 & 2 \\
\hline Camponotus sp. 10 & 0 & 1 & 1 \\
\hline Camponotus sp. 11 & 0 & 2 & 2 \\
\hline Camponotus sp. 12 & 0 & 2 & 2 \\
\hline Camponotus sp. 13 & 1 & 4 & 5 \\
\hline Camponotus sp. 14 & 0 & 3 & 3 \\
\hline Camponotus sp. 15 & 2 & 0 & 2 \\
\hline Ectatomma sp. 1 & 0 & 1 & 1 \\
\hline Ectatomma sp. 2 & 0 & 1 & 1 \\
\hline Hypoponera sp. 1 & 1 & 0 & 1 \\
\hline Pheidole sp. 1 & 2 & 3 & 5 \\
\hline Pheidole sp. 2 & 4 & 3 & 7 \\
\hline Pheidole sp. 3 & 1 & 0 & 1 \\
\hline Pheidole sp. 4 & 0 & 4 & 4 \\
\hline
\end{tabular}

conditions. However, it has been found that, even under laboratory conditions, E. vizottoi's foraging activity peaks in the morning (Vieira et al. 2012). Therefore, it seems that this activity pattern is intrinsic in this species. It is also similar to activity patterns seen in congenerics, as Pie (2004) observed that $E$. opaciventre forages exclusively during the day and has two activity peaks: a larger peak in the morning and a smaller one in the afternoon. On the other hand, E. tuberculatum and E. ruidum forage at night even though they can also forage during the day (Lachaud et al. 1984; Wheeler 1986; McCluskey 1987; Pratt 1989; Lachaud 1990; Passera et al. 1994; Valenzuela-González et al. 1995).

Both dry season and rainy season efficiency indices for E. vizottoi were relatively similar to those found for $E$. brunneum (12.7\%; Giannotti \& Machado 1992) and E. 
opaciventre (9.16\%; Tofolo et al. 2011). In contrast, only the dry season indices of E. vizottoi resembled those found in $E$. ruidum and E. tuberculatum; in the rainy season, the efficiency indices of those two species were $20.3 \%$ and $19.4 \%$, respectively (Lachaud et al. 1996). Although E. vizottoi's efficiency index was similar across the two seasons, the greater availability of prey in the rainy season probably allowed ants to collect food items more easily (Lachaud et al. 1996). In fact, species-specific efficiency indices can vary due to many factors, such as environmental conditions, food resource availability, and variation in abiotic factors.

Our results show that most of the food items collected by E. vizottoi were other arthropods, especially ants (Tables I and II). Workers often used the strategy of foraging in vegetation near the nest to collect water that had accumulated on leaves and sugar-rich substances present in flowers and/ or fruits. These substances also attract other insects upon which these ants often prey.

In previous studies of congenerics, most of the items collected were arthropods (Pratt 1989; Lachaud 1990; Giannotti \& Machado 1992; Schatz \& Wcislo 1999; Tofolo et al. 2011). Similarly, E. tuberculatum most frequently preyed upon other Formicidae and Hymenoptera (Valenzuela-González et al. 1995; Lachaud et al. 1996; Ibarra-Núñez et al. 2001). Although Pie (2004) found that E. opaciventre preyed exclusively or most frequently on termite workers, over $20 \%$ of the species' diet consisted of other ants, mainly Atta spp. Foragers belonging to the genera Camponotus and Pheidole are E. vizottoi's most frequent prey (Table II). This observation can be explained by the abundance of these ants, which are among the most abundant genera worldwide and have varied foraging habits (Hölldobler \& Wilson 1990) (Table I). In fact, Ectatomma permagnum Forel, 1908 was found to prey mostly upon Pheidole and Camponotus (Paiva \& Brandão 1989).

Although more food items were collected in the rainy season (Table I), the variety of items collected during the two seasons was similar. These results contrast with those of Lachaud et al. (1996), who found that E. ruidum's and E. tuberculatum's diets were far more varied during the rainy season due to the large amount of prey available. Tofolo et al. (2011) hypothesized that $E$. opaciventre foragers brought back a low diversity of prey and other ants to the nest because prey variety and ant abundance was limited at the study site. The prey upon which this species primarily feeds may reflect its availability in the natural environment, and the relative amount of predation on a given prey species is generally proportional to that prey's relative abundance (Dejean 1991; Ibarra-Núñez et al. 2001).

According to Tofolo et al. (2011), E. opaciventre "prefers" other ants not because foragers are selective, but rather because food item diversity in the environment is low. This hypothesis has been supported by results from the laboratory: E. opaciventre workers readily accept other food items, such as mealworms, which are not found in their natural environment. However, E. tuberculatum's "preference" for other ants does not reflect relative resource availability since sympatric E. ruidum has a very diverse diet; although both spe- cies have access to the same range of prey, they occupy different ecological strata (Lachaud et al. 1996).

Overall, foraging strategies seem to depend upon several ecological variables, such as the distribution of food resources in time and space, food size and quality, competition, and predation. A colony should therefore adopt a spatial foraging pattern that allows it to collect food effectively and minimize the chances of encountering competition, in order to minimize energy losses and maximize resource return per unit time (Tofolo et al. 2011). Since nocturnal activity was not considered in this study and resource availability can change at night, we do not know how our characterization of E. vizottoi's diet would differ if the species' foraging activity were observed for a full 24 hours. Richard et al. (2004) and Passera et al. (1994), who respectively investigated $E$. tuberculatum's and E. ruidum's foraging activity, observed that both species' activity was linked with the nocturnal secretion rhythm of nectaries.

Foragers of E. vizottoi have never been observed to recruit other foragers, and they hunt individually, as do $E$. tuberculatum, E. opaciventre, and E. brunneum (Overal 1986; Wheeler 1986; Valenzuela-González et al.1995; Pie 2004; Gomes et al. 2009). In contrast, E. ruidum has been found to lay chemical trails to initiate mass recruitment to rich or difficult-to-harvest food resources and to use graded recruitment as a strategy to obtain food (Pratt 1989; Schatz et al. 1997), even though some past reports state that this species hunts individually. Ectatomminae foragers may use a wide variety of strategies to obtain food while hunting individually; they may show no cooperation while searching for and collecting food or demonstrate varying degrees of cooperation, with different levels of communication and recruitment taking place among nestmates. Furthermore, diets can vary widely among species and can include seeds, fruit, living prey, and/or insect secretions (Hölldobler \& Wilson 1990; Medeiros \& Oliveira 2009; Tofolo et al. 2011).

Our results show that $E$. vizottoi has foraging strategies similar to those of other species in Ectatomma. We highlight the finding that, in spite of their low efficiency indices, colonies adopted strategies that allowed them to successfully obtain food resources while avoiding adverse conditions, including preying on other ant species more frequently. This foraging strategy may arise because resource diversity in the environment is limited (Tofolo et al. 2011) or because, regardless of resource availability, E. vizottoi preferentially preys on other invertebrates and especially other ant species (Lachaud et al. 1996).

\section{ACKNOWLEDGMENTS}

We would like to thank Dr. Yzel Rondon Súarez (UEMS) for his assistance with statistical analyses, Dr. Janet Warner Reid (JWR Associates) and Dr. Jessica Pearce-Duvet (Providing English Services for Scientists) for the revision of the manuscript, CNPq for a scholarship given to the first author and the productivity scholarship given to the second author, and Fundect-MS for the equipment used during this study. 


\section{REFERENCES}

Chagas, A.C.S. \& Vasconcelos, V.O. 2002. Comparação da frequência da atividade forrageira da formiga Pachycondyla obscuricornis (Emery, 1890) (Hymenoptera, Formicidae) no verão e no inverno, em condições de campo. Revista Brasileira de Zoociências 4: 97-109.

De'ath, G. \& Fabricius, K.E. 2000. Classification and regression trees: a powerful yet simple technique for ecological data analysis. Ecology 81: 3178-3192.

Dejean, A. 1991. Adaptation d'Oecophylla longinoda [FormicidaeFormicinae] aux variations spacio-temporelles de la densité des proies. Entomophaga 36: 29-54.

Del-Claro, K. 2004. Comportamento Animal: Uma introdução à ecologia Comportamental. v. 1, Jundiaí, Conceito. 132 p.

Del-Claro, K. \& Oliveira, P.S. 1999. Ant-Homoptera interactions in a Neotropical savanna: the honeydew-producing treehopper Guayaquila xiphias (Membracidae) and its associated ant fauna on Didymopanax vinosum (Araliaceae). Biotropica 31: 135-144.

Fernández, F. 1991. Las hormigas cazadoras del género Ectatomma (Formicidae: Ponerinae) en Colombia. Caldasia 16: 551-564.

Giannotti, E. \& Machado, V.L.L. 1992. Notes on the foraging of two species of ponerine ants: food resources and daily hunting activities (Hymenoptera, Formicidae). Bioikos 6: 7-17.

Gomes, L., Desuó, I.C., Gomes, G. \& Giannotti, E. 2009. Behavior of Ectatomma brunneum (Formicidae: Ectatomminae) preying on dipterans in field conditions. Sociobiology 53: 913-926.

Hahn, D.A. \& Wheeler, D.E. 2002. Seasonal foraging activity and bait preferences of ants on Barro Colorado Island, Panama. Biotropica 34: 348-356.

Hammer, Ø., Harper, D.A.T. \& Ryan, P.D. 2001. PAST: Paleontological Statistics Software Package for Education and Data Analysis. Palaeontologia Electronica 4: 1-9.

Heinrich, B. 1993. The Hot-Blooded Insects: Strategies and Mechanisms of Thermoregulation. Cambridge, Harvard University Press, 601 p.

Hölldobler, B. \& Wilson, E.O. 1990. The Ants. Cambridge, Belknap Press, $732 \mathrm{p}$.

Ibarra-Núñez, G., García, J.A., López, J.A. \& Lachaud, J.-P. 2001. Prey analysis in the diet of some ponerine ants (Hymenoptera: Formicidae) and web-building spiders (Araneae) in coffee plantations in Chiapas, Mexico. Sociobiology 37: 723-755.

Lachaud, J.-P., López-Méndez, J.A., Shatz, B., De Carli, P. \& Beugnon, G. 1996. Comparaison de l'impact de prédation de deux ponérines du genre Ectatomma dans un agroécosystème néotropical. Actes des Colloques Insectes Sociaux 10: 67-74.

Lachaud, J.-P. 1990. Foraging activity and diet in some Neotropical ponerine ants. I. Ectatomma ruidum Roger (Hymenoptera, Formicidae). Folia Entomológica Mexicana 78: 241-256.

Lachaud, J.-P., Fresneau, D. \& García-Pérez, J. 1984. Étude des stratégies d'approvisionnement chez 3 espèces de fourmis ponérines (Hymenoptera, Formicidae). Folia Entomológica Mexicana 61: 159-177.

Majer, J.D., Delabie, J.H.C. \& Smith, M.R.B. 1994. Arboreal ant community patterns in Brazilian cocoa farms. Biotropica 26: 73-83.

McCluskey, E.S. 1987. Circadian rhythm in the tropical ant Ectatomma (Hymenoptera: Formicidae). Psyche 94: 245-251.

Medeiros, F.N.S. \& Oliveira, P.S. 2009. Season-dependent foraging patterns: case study of a Neotropical forest-dwelling ant (Pachycondyla striata; Ponerinae), p. 81-95. In: Jarau, S. \& Hrncir, M. (eds.). Food Exploitation by Social Insects: Ecological, Behavioral, and Theoretical Approaches. Boca Raton, Taylor \& Francis Group, 348 p.

Nielsen, M.G. 1986. Respiratory rates of ants from different climatic areas. Journal of Insect Physiology 32: 125-131.

Oliveira, P.S. \& Brandão, C.R.F. 1991. The ant community associated with extrafloral nectaries in Brazilian cerrados, p. 198-212. In: Cutler, D.F. \& Huxley, C.R. (eds.). Ant-Plant Interactions. Oxford, Oxford University Press, $601 \mathrm{p}$.
Overal, W.L. 1986. Recrutamento e divisão de trabalho em colônias naturais da formiga Ectatomma quadridens (Fabr.) (Hymenoptera: Formicidae: Ponerinae). Boletim do Museu Paraense Emílio Goeldi, Série Zoologia, 2: 113-135.

Paiva, R.V.S. \& Brandão, C.R.F. 1989. Estudos sobre a organização social de Ectatomma permagnum Forel, 1908 (Hymenoptera: Formicidae). Revista Brasileira de Biologia 49: 783-792.

Passera, L., Lachaud, J.-P. \& Gomel, L. 1994. Individual food source fidelity in the Neotropical ponerine ant Ectatomma ruidum Roger (Hymenoptera Formicidae). Ethology, Ecology and Evolution 6: 13-21.

Perfecto, I. 1990. Indirect and direct effects in a tropical agroecosystem: the maize-pest-ant system in Nicaragua. Ecology 71: 2125-2134.

Pie, M.R. 2004. Foraging ecology and behavior of the ponerine ant Ectatomma opaciventre Roger in a Brazilian savannah. Journal of Natural History 38: 717-729.

Pol, R. \& Casenave, J.L. 2004. Activity patterns of harvester ants Pogonomyrmex pronotalis and Pogonomyrmex rastratus in the central Monte desert, Argentina. Journal of Insect Behavior 17: 647-661.

Prasad, A.M., Iverson, L.R. \& Liaw, A. 2006. Newer classification and regression tree techniques: bagging and random forests for ecological prediction. Ecosystems 9: 181-199.

Pratt, S.C. 1989. Recruitment and other communication behavior in the ponerine ant Ectatomma ruidum. Ethology 81: 313-331.

Richard, F.-J., Dejean, A. \& Lachaud, J.-P. 2004. Sugary food robbing in ants: a case of temporal cleptobiosis. Comptes Rendus Biologies 327: 509-517.

Schatz, B., Lachaud, J.-P. \& Beugnon, G. 1997. Graded recruitment and hunting strategies linked to prey weight and size in the ponerine ant Ectatomma ruidum. Behavioral Ecology and Sociobiology 40: 337-349.

Schatz, B. \& Wcislo, W.T. 1999. Ambush predation by the ponerine ant Ectatomma ruidum Roger (Formicidae) on a sweat bee Lasioglossum umbripenne (Halictidae), in Panama. Journal of Insect Behavior 12: 641-663.

Tofolo, V.C., Giannotti, E., Moleiro, H.R. \& Simões, M.R. 2011. Diet and spatial pattern of foraging in Ectatomma opaciventre (Hymenoptera: Formicidae) in an anthropic area. Sociobiology 58: 607-620.

Traniello, J.F.A., Fujita, M.S. \& Bowen, R.V. 1984. Ant foraging behavior: ambient temperature influences prey selection. Behavioral Ecology and Sociobiology 15: 65-68.

Traniello, J.F.A. 1989. Foraging strategies of ants. Annual Review of Entomology 34: 191-210.

Valenzuela-González, J., López-Méndez, A. \& Lachaud, J.-P. 1995. Activity patterns and foraging activity in nests of Ectatomma tuberculatum (Hymenoptera: Formicidae) in cacao plantations. Southwestern Entomologist 20: 507-515.

Vieira, A.S. Antonialli-Junior, W.F. \& Fernandes, W.D. 2007. Modelo arquitetônico de ninhos da formiga Ectatomma vizottoi Almeida (Hymenoptera, Formicidae). Revista Brasileira de Entomologia 51: 489-493.

Vieira, A.S., Antonialli-Junior, W.F., Fernandes, W.D., Tofolo, V.C. \& Giannotti, E. 2009. Description of the immature and adult stages of Ectatomma vizottoi (Formicidae: Ectatomminae). Sociobiology 53: 27-38.

Vieira, A.S., Fernandes, W.D. \& Antonialli-Junior, W.F. 2010. Temporal polyethism, life expectancy, and entropy of workers of the ant Ectatomma vizottoi Almeida, 1987 (Formicidae: Ectatomminae). Acta Ethologica 13: 23-31.

Vieira, A.S. Fernandes, W.D. \& Antonialli-Junior, W.F. 2012. Behavioral differentiation and ovarian development of unmated gynes, queens, and workers of Ectatomma vizottoi Almeida 1987 (Formicidae, Ectatomminae). Psyche 2012: 1-8.

Wheeler, D.E. 1986. Ectatomma tuberculatum: foraging biology and association with Crematogaster (Hymenoptera, Formicidae). Annals of the Entomological Society of America 79: 300-303.

Wilkinson, L. 2000. SYSTAT 10. Chicago, IL: SPSS Inc.

Zavatini, J.A.1992. Dinâmica climática no Mato Grosso do Sul. Geografia 17: 65-91.

Received 1 October 2012; accepted 5 September 2013

Associate Editor: Marcio R. Pie 